\title{
Comprehension and Translation of Arabic Metaphor by Non-Native Learners of Arabic
}

\author{
Tawfiq Omar \\ Language Center, The University of Jordan, Amman 11942, Jordan
}

\begin{abstract}
The present study investigates comprehension of Arabic metaphors (istica:rah) by learners of Arabic as a second language. It examines the most three common types of metaphor studied by non-native speaker of Arabic especially at the advanced level. It also investigates to what extent non-native Arabic learners understand these metaphors in addition to exploring the problems associated with understanding certain types of Arabic metaphor. This study also seeks to provide a guideline for teachers on how to present and approach metaphor in the classroom. Keywords: metaphor comprehension, language acquisition, psycholinguistics.
\end{abstract}

DOI: $10.7176 / \mathrm{JEP} / 11-36-05$

Publication date: December $31^{\text {st }} 2020$

\section{Introduction}

In his De Poetics, Aristotle wrote that the greatest thing by far is to have a command of metaphor. This alone cannot be imparted by another; it is the mark of genius, for to make good metaphors implies an eye for resemblances (cited in García Landa 1987). Terence Hawkes reminds us that the word metaphor comes from the Greek metaphora, which derives from meta, meaning "over," and pherein, meaning "to carry" (cited in Garfield 1986). In this sense, certain aspects from one object or entity are carried over to another object and entity. A metaphor then is a statement characterizing one thing in terms of another, where the two are normally considered to be unlike (Gentner and Bowdle 2006). Thus, we say "teachers are stars" borrowing concepts from two different domains by which we think of something in terms of something else. Metaphors are usually easy to identify by native speakers of the language and are easily differentiated from other literal, non-metaphoric forms in the same language. Understanding metaphor by non-native speakers of a language to which a metaphor belongs may posit some challenges to the learner mixing its use with literal statements about things or experiences. Figurative language indeed enhances a foreign learner's comprehension, rhetoric and mastery of the language but adds more pressure on the learner's part when it comes to comprehending the figurative aspects of language such as metaphor. Arabic figurative language is no exception. Understanding metaphors by non-native speakers of Arabic is a very important stage in learners' linguistic growth and development. Arabic uses metaphor in almost all walks of life and on daily basis weather be it through written or spoken discourses.

Metaphor is one of the most fundamental figures of speech and figurative language. Many of our popular idioms and expressions we use on day-to-day basis whether in written or spoken discourses rely on metaphor to convey information and meaning. Metaphor is an important component of linguistic and cultural cognition of any language. Understanding of metaphor transcends the learner beyond the monotony and literal text to dimensions of higher thinking order and language appreciation. Metaphors are found in literary texts and are analyzed linguistically. Upon personal observation, non-native learners of Arabic do find comprehension and use of Arabic metaphor to be very perplexing at often times due to its different types and elevated terminology.

In 1980, Lakoff and Johnson introduced Conceptual Metaphor Theory (CMT) which according to Kövecses (2017: 1) is:

Understanding one domain of experience (that is typically abstract) in terms of another (that is typically concrete). This definition captures conceptual metaphors both as a process and a product. The cognitive process of understanding a domain is the process aspect of metaphor, while the resulting conceptual pattern is the product aspect

According to conceptual mapping, metaphorical expressions derive from an underlying conceptual metaphor. Grady (1997) further elaborates that primary metaphors link different concepts that arise from primary scenes and their correlations. The source concepts for the primary metaphors have some kind of content which is tied to physical perception or sensation like the urge to itch or perception of shapes and weight that involve direct perception of features of our bodies or our environments. For instance, children in some parts of the Arab world play their own version of hide and seek by saying 'hot' or 'cold' when being close of far from an object. (Ferreira 2008) argues that the literal meaning is not intended here but the underlying conceptual metaphor 'proximity is heat' which is a primary metaphor motivated by the basic perceptual experience of warmth, of being close to the mother's body when we are born. What this means is that, to some extent, determining metaphoric concepts has to do with cognitive development from an early age but does this apply to learners of other languages and is there awaiting activation? Is the figurative understanding of propositions based on universals or is native language oriented based on experience or both? 
Kövecses (2017) posits that the conceptual domain from which we draw metaphorical expressions to understand another conceptual domain is called source domain, while the conceptual domain that we try to understand through the use of the source domain is the target domain. In love is a journey, arguments are buildings and ideas are food, the concepts of love, arguments and ideas for example are target domains while journeys, buildings, food, are source domains.

Metaphors are used in Modern Standard Arabic (MSA) and in spoken Arabic (SA) as well. This paper examines one type of Arabic metaphor termed istica:rah literally meaning borrowing which is an intensified comparison in which one term, either the topic (المشبه) almushabbah or the vehicle (المشبه به) almushabbah bihi is omitted The essence of Arabic metaphor is when a word is borrowed from something for which it is known and applied to something for which it is not known (Dabaghi and Mohaghegh 2013). Metaphor in Arabic has another component which is وجه الثبه wajh ashhabah (ground of similarity) and this is the link between the vehicle and topic. In the sentence:

$$
\begin{aligned}
& \text { رأيثُ أسداً يتكلم في المحاضرة } \\
& \text { ra?aytu asadan yatkalmu fil muha:dara } \\
& \text { I saw a lion speaking in class }
\end{aligned}
$$

The person I saw is the topic, أسد' 'lion' is the vehicle and the ground of similarity is the semantic feature 'courage and fearlessness' established through the link between the topic and vehicle with a semantic clue preventing the interpretation of the literal meaning.

There are many types and subtypes of metaphor in Arabic. This study is limited to and depicts the comprehension of the most relevant three famous types that are taught to advanced Arabic non-native learners at the Language Center at The University of Jordan and at Grand Valley State University in the United States of America. Abdul-Raof (2006) writes about different types of metaphor and the different relations that bind the components of metaphor. This study shall cover three metaphors, namely, istica:ra tasri:hiyyah (explicit metaphor) which is a mode of discourse whose vehicle element is maintained but its topic element is deleted as in:

$$
\begin{aligned}
& \text { أحذر سيفاً بين فكيك } \\
& \text { ihdhar sayfan bayna fakkayk }
\end{aligned}
$$

Beware of the sword between your two jaws

The topic لسان 'tongue' is deleted but can be predicted through the lexical clue (بين فكيك - between your two jaws). The second type is istica:ra makniyyah (implicit or indirect metaphor) which is achieved through the ellipsis of the vehicle element from a given proposition, as in:

\section{لسلمى أسنان يقدر ثمنها الجو هري \\ lisalma asnan yuqqdiru thamnaha aljawharii}

Salma has got teeth whose value can only be appreciated by a jeweler

This means that Salma has teeth like pearls. The semantic clue (يقدر ثمنها الجوهري - whose value can only be appreciated by a jeweler) gives prediction to the ellipted element (لؤلؤ - pearls). The third type of metaphor in Arabic is the istica:ra tamthi:liyyah (proverbial or representative metaphor) where the metaphor components are maintained except for the lexical clue because as the name implies, the whole proposition is taken as a proverb. An example of proverbial metaphor said to someone who does not listen to any kind of advice is:

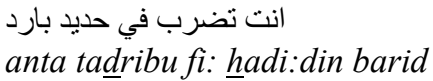

You are beating a dead horse

By studying the comprehension of these three types by non-native learners of Arabic and through comparing outcomes, the researcher is aiming to come up with a teaching-learning strategy that deals with in-class metaphor presentation. Knowing which type of metaphor to present to learners first is not only important in comprehending these three types of metaphor but also is a key component in understanding other types and subtypes of metaphor. It is also a beneficial way to introduce new figurative vocabulary through the introduction of metaphors. In metaphor and second language acquisition there are two views: one view suggests metaphor is creative language that exists mainly in literature and as such is not acquired by children until they are teenagers. The other view is that metaphor is a basic process in language that is universal and as such children are able to produce metaphor at an early age. These conflicting views on the nature of metaphor result in conflicting views as to the acquisition of metaphor. The study therefore aims at providing answers to the following questions:

1. To what extent do learners of Arabic comprehend metaphors in Arabic?

2. Do non-native speakers of Arabic encounter problems with certain types of Arabic metaphor?

\section{Significance of the study:}

Few studies have examined how metaphors and their figurative meanings are comprehended by non-native speakers of Arabic. Most studies focused on the translatability of metaphors across languages not focusing primarily on the relation between acquiring metaphors, comprehending them and the cognitive development of learners. This study is among few that focuses on how non-native speakers of Arabic comprehend Arabic 
metaphors.

\section{Literature review}

Different studies have examined metaphor, the processes of its comprehension and production focusing on the cognitive aspects of metaphor with the mind as a container for metaphor and thought and on practical application and how it relates to aspects of daily life as metaphor is widely used in all ways of communication, everyday language journalism, religious speeches, philosophical and literary writings and scholars begin to realize that the study of metaphor can be connected to many other subjects such as pragmatics, psychology, language teaching and linguistics (Aleshtar and Dowlatabadi 2014). Understanding metaphor has become an integral part in understanding communication and how people view and think about different issues. Lakoff and Johnson (1980) argued that we live by metaphors and that they are present in our thoughts as well as in ordinary, scientific, or literary language. Since then, metaphor has been seen as a conceptual tool for our thoughts and communication. Studies also investigated the acquisition of metaphors which is either used for the mother tongue or for additional languages. Lucia Menezes Oliveira e Paiva (2014) in her "What's in a name? The quest for new metaphors for second language acquisition" argues that metaphors can give us a picture of the complexity of language learning. When a metaphor points to a phenomenon, it highlights one of the aspects of a concept, but hides others and that the metaphors and the metonyms found in her research for both language and language learning can help understand the complex phenomenon of language and language learning. She also talks about the distinction between acquisition and learning. Acquisition is an unconscious process and learning a conscious one and that they do not represent two sides of the same coin and that learning and acquisition are not both parts of the same process. The function of learning is simply monitoring.

Aleshtar and Dowlatabadi (2014) investigated the possible relationship between Iranian EFL learners' metaphoric competence in the EFL classroom and their language proficiency. They concluded that participants' language proficiency is positively correlated with their metaphoric competence and that participants with higher language proficiency will be more metaphorically competent. They studied the concept of metaphoric competence and L2 studies on metaphoric competence taking into consideration the cognitive view of metaphor. Their subjects were twenty-five males and thirty-five females all Iranian learners majoring in English Literature at Arak University, Iran. The participants were selected from the freshman and junior students and then have been classified to low and high proficiency groups, respectively. The researchers conducted two proficiency tests, one is English language proficiency test and the other is English Conventional Metaphor Proficiency Test (ECMPT). They concluded that metaphoric competence and language proficiency correlate with each other significantly, that is, L2 learners who enjoy high language proficiency can comprehend and produce metaphors and that metaphoric competence can be used as a factor to determine the general proficiency of the EFL learners.

Doiz and Elizari (2013)) highlighted the importance of the role of metaphors in the acquisition of figurative vocabulary by learners of English in two contexts, an EFL classroom and a content and language integrated learning (CLIL) classroom. Their aim was to show that metaphor awareness is instrumental in the accomplishment of two objectives: the learning of new figurative vocabulary in English and the understanding of the subject-matter targeted in the lesson plan. The authors we reported on the effectiveness of working on metaphor awareness for the comprehension and retention of figurative language. They compared the students' comprehension and retention rates of the new expressions which had been presented in two different ways, namely, the traditional or translationbased approach and the cognitive approach based on the systematic explanation of the target expressions. Their subjects were 40 first-year baccalaureate students in a state-run school located in Navarre, Spain who were equal in terms of their English proficiency level. Descriptive statistics data showed that the experimental group performed significantly better than the control group. Analysis also showed that relating figurative expressions to their underlying conceptual metaphors helped learners understand and spontaneously retain the target items.

Raii (2008) examined the pervasiveness of metaphorical constructions in day-to-day variety of language and claimed in accordance with Lakoff and Johnson (1980) that the metaphorical expressions are not mere words, but they are part and parcel of our everyday speech and the way we conceptualize things and that metaphor is not restricted to poetic language or the literary style. The author examined the Cognitive theory of metaphor and the claim by cognitive linguists that the proper place of metaphor is in our cognitive system, where it plays an important role in characterizing the structure of abstract concepts, making us understand abstract concepts via more concrete ones. The author cited examples from Spoken Syrian Arabic (SSA) taken from Lathiqiia speech community. He provided metaphors about time, argument is war, ideas and speech are food and commodities, states and changes are locations and difficulties are impediments to motion among many. In conceptualizing time, the author for example cites the following examples:

$$
\text { إجاوقت الجد }
$$

Ija waqt il jad

the time of seriousness has come 
مر تشرين بسرعة

Mar tishri:n bsurca

October passed fast

The author also cites some exapmles about argument is war metaphor as if arguments have weapons as

in:

$$
\begin{aligned}
& \text { حكيو فقعني } \\
& \text { Hakyu fa?cni } \\
& \text { His speech split me } \\
& \text { Hakyu madafic } \\
& \text { His speech is guns }
\end{aligned}
$$

\section{Data collection and methodology}

Participants of the study are ten non-native speakers of Arabic who are studying at the Language Center at The University of Jordan during the spring semester of 2019. Participants are from the advanced level namely, level eight of Arabic who sat for an Arabic placement test at the beginning of their training program. During the spring of 2019, the Language Center is offering eight levels of Arabic with levels six, seven and eight classified as advanced. The data were elicited through a written task which consisted of nine metaphors representing the three types of metaphor, three for each type. Subjects were guided verbally to write down the meaning of each underlined contextualized metaphor. All students reported comprehension of the context sentences that hosted the metaphors. The metaphors chosen as examples of the three types were checked for appropriateness and soundness by two professors of Arabic at the University of Jordan. The subjects were instructed to write down the meaning of each metaphor in a blank space provided and to write 'I do not know' in Arabic or in English if they do not know the meaning of the intended ones. Correct answers or approximations of correct answer were counted in addition to wrong and 'I do not know' responses then percentages were calculated and analyzed. Examples and subjects' answers were transcribed using a three layered transcription: examples and answers were written in Arabic, transliterated using Roman alphabet and then an equivalent meaning was provided.

(Sheehan 2005) proposes three stages learners or hearers must go through in order to comprehend the intended metaphorical meaning of an utterance. Firstly, the hearer must possess some strategy to determine whether or not they need to find a metaphorical interpretation for the utterance at all as from face value of some utterances, they are excluded as metaphors. Secondly, once the learner determines that it is necessary to look further for metaphorical interpretation, there must be some set of principles for the computation of the possible metaphorical meanings of the utterance. Thirdly, given their knowledge of the subject, strategies should be for limiting the range of metaphorical meanings to just those that apply to the subject.

\section{Findings and results}

The data elicited revealed high scores in the proverbial metaphors with correct answers of $\% 93$, followed by the implicit metaphor with a score of $\% 80$ and lastly the explicit metaphor category with \%33. Table 1 and 2 below shows these percentages.

Table 1: Percentages of correct responses on the meaning of types of metaphors.

\begin{tabular}{|l|l|l|}
\hline Explicit metaphor & $\% 33$ \\
\hline Implicit metaphor & $\% 80$ \\
\hline Proverbial metaphor & الاستعارة التصريحتعنية الاستعارة التمثيلية & $\% 3$ \\
\hline
\end{tabular}

Table 2: Percentages for each example correct answers.

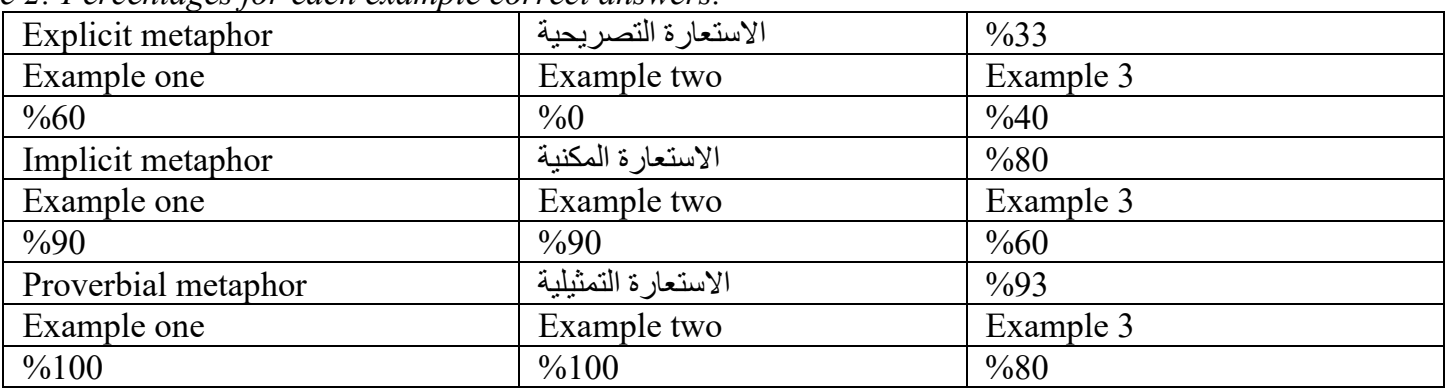

Analyzing the third type which is الاستعارة التمثيلية (proverbial metaphor), subjects provided \%100 correct responses to examples one and two and \%80 for example three. In example one:

$$
\begin{aligned}
& \text { أضرب في حديد بارد } \\
& \text { Adribu fi: hadi:d barid }
\end{aligned}
$$


Beat a dead horse.

Some of subjects' responses were as follows:

لا يوجد فائدة، لم أحصل على نتيجة (1.1)

La yu:jad farida, lam ahsul la nati:ja

There is no use, I did not get any result

$$
\text { رفض نصيحتي }
$$

Rafada nasi: $\underline{\text { hati: }}$

He turned down my advice.

In example two, all gave correct answers to:

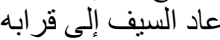

'a:da assayfu ila qirabihi

War ended (lit. the sword went back to its scabbard)

In example three:

ل ل

Likuli jawadin kabwa

Nobody is perfect or successful all the time (lit. Any horse may stumble)

Two answered incorrectly. One wrote an incorrect response and another answered by 'I do not know' a strategy seldomly used by participants.

كل شيء يحدث لسبب (3.1)

Kul shai? yahduth lisabab

Everything happens for a reason

In type one metaphors, namely explicit metaphors, many incorrect answers were given. Interesting though is that many instructors of Arabic start with this type when introducing Arabic metaphor to non-native speakers of Arabic. Only $\% 33$ answered correctly with example number two astonishingly scoring $\% 0$ of correct answers. Metaphors that were expected to be easily understood by non-native learners scored the lowest. In example one of type one metaphor, \%33 got it right:

(4) الحروب تأكل الأخضر و اليابس

Al huru:b tikul al akhdar w alyabis

Wars turn everything to ashes. (lit. wars eat the green and the dry)

Some of subjects' correct responses were as follows:

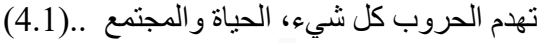

Tahdim al huru:b kul Shai?, al haya w al mujtama

Wars ruin everything, life and society ...

تذمر الكثير من الأشياء(4.2)

Tudammir al kathi:r min al ashya?

Ruin many things

Metaphor two which scored \%0 was as follows:

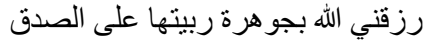

Razaqani Allah bijawhara rabbaytuha Ta assidq

God gave me a daughter that I raised to be honest. (lit. God granted me a jewel which I raised to be honest) Almost all the attempts missed the figurative meaning and focused on the literal meaning especially the one connected to richness and wealth. Subjects did not examine the lexical clues present in the context sentence that eliminates the literal meaning of 'jewel'. A sample of their answers came as follows:

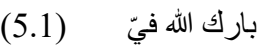

Baraka allahu fii

God blessed me

منحني الله ثروة

Manahani allahu tharwa

God gave me a fortune

Subjects seems to fall short of accessing the second stage of Chouinard, Volden, Hollinger, and Cummine (2018). They propose three metaphor comprehension stages that involve the following: (1) accessing the relevant information about the words that make up the utterance; (2) integrating the relevant information to generate the literal and nonliteral meanings; and (3) selection of the intended meaning which requires inhibition/suppression of the unintended meaning. Subjects had no issues accessing the relevant information about the words that make up the metaphor but when it comes to stage two requiring them to integrate the information to isolate the literal from figurative. Faulty decisions at two will lead to a faulty three which is selecting the intended meaning. Subjects of this study read word in isolation in some cases especially in example two of explicit metaphor. It seems rational to think that in type one metaphor, the process of integrating the proper and relevant information about the words in a metaphor is harder than other types. Even if subjects scored high in the $\% 0$ metaphor, the overall score would 
still be low compared to the other two types. What was supposed to be the hardest type to present to learners because of its cultural and historic orientation scored the highest in comprehension! Even according to Sheehan's (2005) framework, participants also seem to struggle with the second stage determining the set of principles for the computation of the possible metaphorical meanings of the utterance.

The subjects of the study seem to be misguided by the literal similarity. Literal similarity comparisons differ from metaphors in that, in literal similarity, many or most properties match, whereas in metaphor only a few properties match (Gentner and Bowdle 2006). They seem to try to establish a structural and functional link by connecting properties of the metaphor elements to create a rational behind their interpretations. One response to metaphor (1) above demonstrates such rational, a reasoning that is justifiable and funny. The context says the following:

$$
\text { أخي الصغير لا يدرس جيداً ويسهر كثير اً ويشاهد الكثير من الأفلام ويدخن كثير اً. حاولت أن انصحه ولكنني أضرب في حديد بارد. }
$$

'My younger brother does not study well, stays up all night, watches too many movies and smokes a lot. I tried to advice and guide him but I was like someone he is beating a dead horse.

أخي كسول وأنا شاطر Adribu fi: hadi:d barid 'Beat a dead horse' was interpreted as أضرب في حديد بارد ana shatir 'my brother is lazy and I am diligent'.

When talking about this type of Arabic metaphor namely alistica:ra, context seem to have a crucial role in comprehending it because context caries some important lexical clues that eliminate the literal meaning and as Gentner and Bowdle (2006:20) suggest, metaphor processing begins with a symmetric alignment, as in the structure-mapping model, rather than by a directional projection from the vehicle to the topic. This is actually the core of this type of Arabic metaphor where either the topic or vehicle is deleted but the relationship is understood from clues. This might be a good reason why some metaphors were mis interpreted. Other factor might play a role in hindering proper understanding and comprehension of metaphor such as the linguistic structure, the role of semantic transparency and the influence of literal distracters in metaphorical comprehension. Of course, some metaphorical expressions are more difficult than others and as the aforementioned factor contribute to misinterpreting a metaphor, they consider a point of strength enabling metaphor comprehension once properly activated.

\section{Conclusion}

Non-native speakers of Arabic at the advanced level where this type of metaphor is usually introduced showed good command and comprehension of Arabic metaphor in context. Upon asking some instructors who teach Arabic to non-native speakers at The Language Center about what type of metaphor they think is hardest to introduce to students, there was almost a consensus that it is type three discussed in this paper as these metaphors have become part of a cultural tradition that might require a background knowledge. The results of this study show that it is the third type that students actually found easier to comprehend. When introducing a new topic to students, it seems rational to start with the easy parts and move on gradually to harder ones to guarantee a gradual and full understanding which will grant students proper access to the topic at hand, in our case Arabic metaphor. Before this research, the author of this paper used to start organizing a lesson plan on Arabic metaphor to present to learners with the hierarchical order presented at the beginning of the paper that is explicit metaphor, implicit metaphor and proverbial metaphor. In introducing Arabic metaphor after this research, a reversal hierarchy will be adopted starting with proverbial metaphor followed by implicit and explicit metaphors respectively. There are many things that are taken for granted when presenting topics to non-natives of the language because people think it is the right way to do it judging from their own point of view and their own perspectives. Things should also be taken from the learners' point of view especially that they come with different linguistic and cultural packaging. Advanced non-native learners seem to comprehend this type of metaphor due to contextualization and due to sufficient Arabic language proficiency but their understanding of metaphors vary as each one of them understood metaphors in some cases differently. There were some problems in comprehending some types of this Arabic metaphor but the general outcomes were satisfactory but contrary to common belief on which types are easier to comprehend.

\section{Recommendations}

The study recommends that instructors and teachers who are involved in teaching Arabic rhetoric to non-natives take such conclusions into account when introducing Arabic metaphor to students. Other studies can also be conducted on other students and on other levels and compare them with the results of this study.

\section{References}

Abdul-Raof, H. (2006). Arabic Rhetoric. London: Routledge.

Aleshtar, T. and Hamidreza D. (2014). 'Metaphoric competence and language proficiency in the same boat'. Procedia-Social and Behavioral Sciences, 98: 1895-1904.

Alkhatib, M. and Khaled, S. (2017). 'Natural language processing for Arabic metaphors: a conceptual approach'. 
In: Aboul Ella Hassanien., Khaled Shaalan, Tarek Gaber, Ahmad Taher Azar, and M. F. Tolba (eds.), Proceedings of the International Conference on Advanced Intelligent Systems and Informatics 2016, Advances in Intelligent Systems and Computing, 533: 170-81.

Chouinard, B., Volden, J., Hollinger, J. and Cummine, J. (2019). 'Spoken metaphor comprehension: Evaluation using the metaphor interference effect'. Discourse Processes, 56 (3): 270-287.

Aintzane, D. and Elizari, C. (2013). 'Metaphoric competence and the acquisition of figurative vocabulary in foreign language learning'. Estudios de Lingüistica Inglesa Aplicada (ELIA), 13: 47-82.

García Landa, J. (1987). 'Aristotle's poetics'. Universidad de Zaragoza. Available at SSRN: https://ssrn.com/abstract=2423697 or http://dx.doi.org/10.2139/ssrn.2423697. (Retrieved on April 2, 2019).

Garfield, E. (1986). 'The metaphor-science connection'. Essays of an Information Scientist, 9: 316-323.

Gentner, D. and Bowdle, B. (2006). 'Psychology of metaphor processing'. In Encyclopedia of Cognitive Science, Nadel Lynn (ed.), 204-2017, Chichester: John Wiley \& Sons, Ltd.

Gibbs, RW, Jr. (1994). 'The poetics of mind: figurative thought, language and understanding'. DELTA: Documentação de Estudos Em Lingüística Teórica e Aplicada 13 (2): 341-50.

Grady, J. (1997). Foundations of meaning: primary metaphors and primary scenes. Unpublished Ph.D. thesis, University of California, Berkeley.

Himdad, M. (2015). A Syntactic-Semantic Study of Metaphor in Modern English Journalism. Saarbrücken: LAMBERT Academic Publishing.

Kövecses, Z. (2017). 'Conceptual metaphor theory'. The Routledge Handbook of Metaphor and Language, Elena Semino and Zsófia Demjén (eds.), 13-27, Abingdon: Routledge.

Lakoff, G. and Johnson, M. (2003). Metaphors We Live By. Chicago: University of Chicago Press.

Vera, LMO. (2014). 'What's in a name? The quest for new metaphors for second language acquisition'. Trabalhos Em Linguística Aplicada 53 (1): 145-62.

Raii, J. (2009). 'Metaphor in day-to-day Arabic speech: a conceptual approach'. Tishreen University Journal for Research and Scientific Studies - Arts and Humanities Series 31 (1): 175-193.

\section{Appendix}

Table 1: Transliteration symbols for Arabic vowels and some consonants

\begin{tabular}{|c|c|c|c|}
\hline Arabic alphabet & Symbol & Example & Meaning \\
\hline 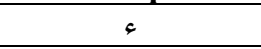 & $?$ & Pamal & hope \\
\hline$\dot{H}$ & th & thaclab & fox \\
\hline ج & $\mathrm{j}$ & jamal & camel \\
\hline$\tau$ & $\underline{\mathrm{h}}$ & $\underline{\mathrm{hub}}$ & love \\
\hline$\dot{\tau}$ & $\mathrm{kh}$ & khubz & bread \\
\hline$j$ & $\mathrm{Z}$ & zi:t & oil \\
\hline ش & sh & shams & sun \\
\hline ص & $\underline{\mathrm{S}}$ & $\underline{\mathrm{s}}$ ayf & summer \\
\hline ض & $\underline{\mathrm{d}}$ & $\underline{\mathrm{d}}$ ayf & guest \\
\hline b & $\mathrm{t}$ & $\mathrm{ti}: \mathrm{n}$ & mud \\
\hline ظ & $\mathrm{TH}$ & THuhr & noon \\
\hline$\varepsilon$ & $\mathrm{c}$ & cabd & slave \\
\hline$\dot{\varepsilon}$ & gh & gharb & west \\
\hline ق & $q$ & qalam & pencil \\
\hline 9 & $\mathrm{~W}$ & ward & rose \\
\hline ي & $\mathrm{y}$ & yawm & day \\
\hline (فتحة) & $\mathrm{a}$ & kataba & he wrote \\
\hline لُ & $\mathrm{u}$ & kutub & books \\
\hline (كسرة). & $\mathrm{i}$ & $\sin$ & tooth \\
\hline مد طويل إى & $\mathrm{a}:$ & ka:tib & writer \\
\hline ضمة طويلة و & $\mathrm{u}:$ & fu:1 & beans \\
\hline كسرة طويلة ي & i: & fi: 1 & elephant \\
\hline $\begin{array}{c}\text { Diphthongs } \\
\text { (أصوات علة مركبة) }\end{array}$ & aw & mawt & death \\
\hline
\end{tabular}

